\title{
MOKINIŲ RŪKYMO IR SU JUO SUSIJUSIO ELGESIO KITIMAI KAUNO RAJONE 2005-2012 METAIS
}

\author{
Antanas Goštautas' ${ }^{1}$, Romualdas Žekas ${ }^{2}$, Laurynas Dilys ${ }^{\mathbf{3}}$, Nijolė Goštautaitė-Midttun ${ }^{4}$ \\ ${ }^{1}$ Vytauto Didžiojo universitetas, ${ }^{2}$ Kauno rajono savivaldybè, ${ }^{3}$ Visuomenès sveikatos biuras, \\ ${ }^{4}$ Psichikos sveikatos iniciatyva
}

Raktažodžiai: mokinių rūkymas, rūkymo kitimai, Pasaulio jaunimo rūkymo tyrimas (GYTS), Kauno rajonas, požiūris ị rūkymą, rūkymo prevencija.

\section{Santrauka}

Kauno rajono mokyklose 2002-2005 laikotarpiu nustatyti mokiniu rūkymo ir su juo susijusio elgesio pokyčiai palankūs jų sveikatai bei intensyvaus mokymo rūkymo profilaktikos priemonių efektyvumas. Šio straipsnio tikslas nustatyti tolimesnius rūkymo, požiūrių ir elgesio, susijusio su rūkymu, kitimus 2005-2012 metais Pasaulio jaunimo rūkymo tyrimo - Global Youth Tobacco Survey (GYTS) metodologijos kontekste. Taikant išplèstą GYTS klausimyną 2005 ir 2012 metais atitinkamai apklausti 3250 ir 1800 septintų-devintų klasių mokiniai. Suskirsčius klausimus apie rūkymą i 6 temines grupes, 2012 metų tyrime lyginant su 2005 metais statistiškai patikimai sumažejo procentas berniukų, bandžiusių rūkyti $(p<0,05)$ bei rūkiusių kitoki tabako produktą negu cigaretes per 30 dienų, tačiau padidèjo procentas mokinių, kurie tvirtai mano pradèti rūkyti per ateinančius 12 mènesių, mano, kad rūkantys berniukai turi daugiau draugų $(\mathrm{p}<0,05)$. Sumažèjo procentas mokinių, gyvenančių namuose, kuriuose rūkoma, rūkančių savo namuose, perkančių cigaretes parduotuvejje. Tačiau 2012 m. didesnis perkančiujų cigaretes parduotuvèje mokinių procentas nurode, kad jiems pardavė cigaretes, neatsižvelgiant $i$ jų amžių. 2012 metais mažesnis procentas norinčių mesti rūkyti mokinių gavo pagalbą ar palaikymą mesti rūkyti. Sumažejo mokinių procentas mačiusių per 30 dienų bent vieną cigarečiu reklamą laikraščiuose ar žurnaluose, procentas mokinių, kuriems buvo pasiūlyta cigarečiu nemokamai ar turinčių daiktą su cigarečių firmos logotipu. Didesnis procentas mokinių 2012 m. nurodè, kad jiems pamokų metu buvo kalbèta apie rūkymo pavojus, tačiau mažesnis negu nustatytas Lietuvos GYTS tyrime 2009 metais. Tarp Kauno rajono mokyklų septintų - devintų klasių mokinių, 2005-2012 metų laikotarpiu nustatyti sveikatai palankūs tęstiniai rūkymo paplitimo, požiūrio ir elgesio pokyčiai, tačiau rūkymo lygis išlieka pavojingas jų sveikatai.

\section{Ivadas}

1975 metais Pasaulio sveikatos organizacija (PSO) paskelbė „su rūkymu susijusių ligų pasekmès neịgalumui ir nesavalaikei mirčiai išsivysčiusiose šalyse yra tiek svarbios, jog cigarečių rūkymo kontrolè gali prisidèti prie sveikatos pagerejjimo ir gyvenimo pratęsimo šiose šalyse daugiau negu bet kuri kita skyrium paimta priemone (veiksmas) visoje prevencineje medicinoje“ [1]. Šių teiginių atitikimas tikrovei patvirtintas moksliniais tyrimais [2], priimti tarptautiniai, strateginiai dokumentai rūkymo paplitimui mažinti [3], tabako gamybą ir vartojimą reguliuojantys įstatymai. Daugelyje valstybių vykdomi tūkstančiai rūkymo profilaktikos - intervencinių programų. Čia cituojama PSO rezoliucija apie tabaką išlieka aktuali ir dabar, praejus beveik 40 metų. 2012 metais PSO veiklos ataskaitoje pažymima, jog rūkymas ir žalingas alkoholio vartojimas yra du svarbiausi rizikos veiksniai, didinantys ligotumo, neigalumo ir mirtingumo rodiklius, o jų paplitimo ir vartojimo lygis išlieka visose populiacijose, nežiūrint, kad žinios ir technologijos yra visiems prieinamos. Todèl profilaktinis poveikis šiems rizikos veiksniams ir dabartiniu metu išlieka prioritetinis [4]. Kita vertus, tokia lèta profilaktinès veiklos pažanga patvirtina, jog šie rizikos veiksniai yra kompleksiški ir įsišakniję visuomenèje. Lietuvoje šiuo laikotarpiu rūkymo paplitimas buvo tiriamas atskirais (pavieniais) klausimais, ijungtais PSO organizuotose tęstinèse suaugusiujjų ir jaunimui skirtose sveikatos programose - KRIS (1972 -1974) [5], MONICA - PSY (1984 -1992) [6], ESPAD [7], HBSC [8]. Tačiau keliais klausimais nei̇manoma nustatyti ir ịvertinti sudètinio rūkymo reiškinio, kuris priklauso nuo socialinių veiksnių (tabako industri- 
jos), îstatymų, visuomenès nuostatų, asmens psichologinès savireguliacijos bei biologinio potraukio - priklausomybès nuo tabako formavimosi mechanizmo. Šie rūkymą veikiantys veiksniai didelès apimties paauglių rūkymo tyrimuose pradèti plačiau tyrinèti siejant rūkymo pradžią paauglystėje su psichologiniais ir socialiniais veiksniais Pasaulio jaunimo tabako tyrime - Global Youth Tobacco Survey (GYTS) [9]. Ši programa nuo 2000 metų koordinuojama JAV ligu kontrolès ir prevencijos centrų (U.S. Centers for Disease Control and Prevention-CDC) ir Pasaulinès sveikatos organizacijos (PSO), yra skirta mokinių rūkymo profilaktikos efektyvumo įvertinimui ir šalies mokinių rūkymo profilaktinių programų sudarymui $[9,10]$. Lietuvoje epidemiologinio pobūdžio mokinių rūkymo profilaktikos tyrimų pradžia - PSO integruotos neinfekcinių ligų profilaktikos programos dalis, skirta paaugliams. Ja remiantis buvo įvykdytas keturių metų pradinių klasių mokinių rūkymo psichologinès prevencijos galimybių tyrimas Jonavos ir Biržų administracinių rajonų mokyklų pradinėse klasėse 1986 - 1990 metais. Šis projektas tapo moksliniu pamatu Lietuvos SAM Nacionalinei dvylikos metų mokinių rūkymo profilaktikos programai (1992 -1994 m.) [11], o ją išaldžius, fragmentiškiems projektams, igyvendinamiems Kaune ir Kauno rajone. Remiant Kauno rajono savivaldybei, bendradarbiaujant su VDU ir Lietuvos sveikatos psichologų sajunga (LSPS) mokyklose buvo išplètoti koordinuojami, tęstiniai mokinių rūkymo profilaktikos projektai. Remiantis tuometinès Nacionalinės mokiniu rūkymo profilaktikos programos metodologija buvo atliekami specialūs tyrimai ir profilak-

1 lentelè. Mokinių rūkymo paplitimas ir požiūris ị rūkymą Pastaba: Ženklas " reiškia statistiškai patikima $(p<0,05)$ skirtuma tarp pirmo $(2005$ m.) ir kartotinio (2012 m.) tyrimu rezultatu. Ženklo nebuvimas reiškia p $>0,05$

\begin{tabular}{|c|c|c|c|c|}
\hline \multirow{3}{*}{$\begin{array}{l}\text { Klausimai } \\
\text { (Teiginiai) }\end{array}$} & \multicolumn{4}{|c|}{ Tyrimo metai, atsakymai (abs. sk., proc) } \\
\hline & \multicolumn{2}{|c|}{$2005 \mathrm{~m}$. } & \multicolumn{2}{|c|}{$2012 \mathrm{~m}}$. \\
\hline & Berniukai & Mergaitės & Berniukai & Mergaitès \\
\hline $\begin{array}{l}\text { Bent kartą rūkè } \\
\text { cigaretes }\end{array}$ & $\begin{array}{l}1034 \\
\mathbf{7 1 , 3}\end{array}$ & $\begin{array}{r}750 \\
\mathbf{5 1 , 6}\end{array}$ & $\begin{array}{l}617 \\
67,1^{*}\end{array}$ & $\begin{array}{c}548 \\
\mathbf{5 6 , 0 *}\end{array}$ \\
\hline $\begin{array}{l}\text { Per } 30 \text { dienų rūkè } \\
\text { kitą nei cigaretès } \\
\text { tabako gamini }\end{array}$ & $\begin{array}{l}240 \\
\mathbf{1 7 , 3}\end{array}$ & $\begin{array}{l}113 \\
7,8\end{array}$ & $\begin{array}{l}120 \\
\mathbf{1 3 , 2 *}\end{array}$ & $\begin{array}{l}116 \\
11,9 *\end{array}$ \\
\hline $\begin{array}{l}\text { Per } 30 \text { dienų rūkè } \\
\text { cigaretes }\end{array}$ & $\begin{array}{l}334 \\
\mathbf{2 3}, 1\end{array}$ & $\begin{array}{r}195 \\
\mathbf{1 3 , 5}\end{array}$ & $\begin{array}{l}227 \\
\mathbf{2 4 , 9}\end{array}$ & $\begin{array}{l}163 \\
\mathbf{1 6 , 7}\end{array}$ \\
\hline $\begin{array}{l}\text { Tvirtai mano } \\
\text { pradèti rūkyti per } \\
\text { ateinančius } 12 \\
\text { mėnesių }\end{array}$ & $\begin{array}{r}79 \\
\mathbf{5 , 5}\end{array}$ & $\begin{array}{l}43 \\
\mathbf{3 , 0}\end{array}$ & $\begin{array}{c}67 \\
\mathbf{7 , 3}^{*}\end{array}$ & $\begin{array}{c}50 \\
\mathbf{5 , 1 *}\end{array}$ \\
\hline $\begin{array}{l}\text { Mano, kad rūkantys } \\
\text { berniukai turi } \\
\text { daugiau draugu }\end{array}$ & $\begin{array}{l}404 \\
\mathbf{2 8 , 6}\end{array}$ & $\begin{array}{r}340 \\
23,6\end{array}$ & $\begin{array}{c}304 \\
\mathbf{3 3 , 3}\end{array}$ & $\begin{array}{c}392 \\
\mathbf{4 0 , 2}^{*}\end{array}$ \\
\hline $\begin{array}{l}\text { Mano, kad rūkantys } \\
\text { berniukai atrodo } \\
\text { patrauklesni }\end{array}$ & $\begin{array}{r}163 \\
\mathbf{1 1 , 4} \\
\end{array}$ & $\begin{array}{r}54 \\
\mathbf{3 , 7} \\
\end{array}$ & $\begin{array}{r}79 \\
8,6^{*}\end{array}$ & $\begin{array}{l}48 \\
4,9\end{array}$ \\
\hline
\end{tabular}

tinis darbas [12]. Tai ženkliai sustiprino bendras rūkymo profilaktikos priemones, taikomas sveikatą stiprinančių mokyklu tinkle ir daugelyje kitų Kauno rajono NVO projektų, apimant visas mokinių klases. Paminètinas vienas iš specializuotų kontroliuojamų jaunesnių klasių mokinių rūkymo prevencijos projektų, skirtu patikrinti psichologinio poveikio mokymo metodu profilaktikos galimybes [13]. Taikytos psichologinio poveikio metodikos padèjo keisti mokinių požiūrị ị rūkymą, tačiau nepakeitè intervencijos laikotarpiu paauglių rūkymo paplitimo. Skatinanti rūkymą aplinkos įtaka buvo stipresnè už tas psichologines mokymo priemones, kurios buvo taikytos projekte. Kita vertus, gausios tęstinès, bendros ir specialios profilaktikos priemonès taikytos visose Kauno rajono mokyklose, kartu imant, pasirodè veiksmingos. Teigiami mokinių rūkymo ir su rūkymu susijusio elgesio pokyčiai buvo nustatyti pritaikius GYTS klausimyną 2002 ir 2005 metais [14]. 2012 metais dèka didesnio Kauno rajono savivaldybès dèmesio, issikūrus visuomenès sveikatos biurui, su darbuotojais mokyklose atsirado galimybė atnaujinti ir sustiprinti profilaktinę veiklą pritaikant anksčiau paruoštus mokinių rūkymo profilaktikos metodus [11,14] ir planuoti Kauno rajono mokyklose tęstinius, ilgalaikius, koordinuojamus mokinių rūkymo profilaktikos darbus. Planuojant didelès apimties tęstinius mokiniu rūkymo profilaktikos darbus, svarbu numatyti efektyvumo ịvertinimą. Foninių rodiklių ịvertinimui Kauno rajono mokyklose 2012 metais pritaikeme nuo 2001 metų mūsų naudotą išplèstą GYTS apklausą [15]. Šio darbo tikslas ịvertinti 2012 metų mokinių rūkymo ir su juo susijusių požiūrio bei elgesio rodiklius, kaip pamatinius rūkymo profilaktikos vertinamuosius rodiklius, bei palyginti juos su ankstesnių tyrimų rezultatais (2005 metų).

\section{Tyrimo objektas ir metodai}

Kauno rajono 7-9 klasių mokinių 2012 metais tyrimas atliktas anksčiau vykdytų mokinių rūkymo profilaktikos darbų kontekste, bendradarbiaujant su NVO Lietuvos sveikatos psichologų sajunga, Psichikos Sveikatos Iniciatyva, kartu su Kauno rajono savivaldybès visuomenès sveikatos biuru. Ištisinę Kauno rajono mokyklų, dviem mokykloms atsisakius dalyvauti tyrime, 7-9 klasių mokinių apklausą atliko biuro darbuotojai ir Vytauto Didžiojo universiteto studentai psichologai, klausantys sveikatos psichologijos kursą. Apklausoje 2012 metais dalyvavo 1800 mokinių. Lyginamojoje grupeje 2005 metais [14] dalyvavo 3250 septintų- devintų klasių Kauno rajono mokyklų mokinių. Tyrimui taikème išplèstą Pasaulio jaunimo tabako tyrimo - Global Youth Tobacco Survey (GYTS) klausimyną, paruoštą vieno iš šio straipsnio autorių, GYTS projekto koordinatoriaus Lietuvoje [15]. Tyrimo analizei klausimai buvo 
suskirstyti ị šešias temines grupes: mokinių rūkymas, cigarečių prieinamumas, rūkymas aplinkoje, metimas rūkyti, informacinès priemonès ir rūkymo reklama, profilaktinis mokymas mokykloje. Atlikta kartotinè $2005 \mathrm{~m}$. tyrimo duomenu analizè patikslinta ir sulyginama su 2012 metų tyrimo duomenimis. Atsakymai i atrinktus klausimus 2012 metų mokinių tyrime palyginti su atsakymais Lietuvos mokyklose ir mokinius reprezentuojančiame GYTS tyrime 2001, 2005 ir 2009 metais [16]. 2005-2012 metu tyrimo duomenų analizei taikytos kontingencijos lenteles ir $\chi^{2}$ kriterijus, naudojant SPSS programinį paketą. Statistinio patikimumo lygmuo nustatytas $\mathrm{p}<0,05$.

\section{Rezultatai}

2005-2012 metų tyrimo rezultatai pateikti lentelèse 1-6.

Iš lentelès 1 matyti, kad 2012 metais lyginant su 2005

2 lentelė. Cigarečiu prieinamumas

Pastaba: Ženklas " reiškia statistiškai patikima $(p<0,05)$ skirtuma tarp pirmo $(2005$ m.) ir kartotinio (2012 m.) tyrimu rezultatu. Ženklo nebuvimas reiškia p>0,05

\begin{tabular}{|l|c|c|c|c|}
\hline \multirow{2}{*}{$\begin{array}{l}\text { Klausimai } \\
\text { (Teiginiai) }\end{array}$} & \multicolumn{4}{|c|}{ Tyrimo metai, atsakymai (abs.sk., proc) } \\
\cline { 2 - 5 } & \multicolumn{2}{|c|}{$\mathbf{2 0 0 5}$ m. } & \multicolumn{2}{c|}{$\mathbf{2 0 1 2} \mathbf{~ m . ~}$} \\
\cline { 2 - 5 } & Berniukai & Mergaitès & Berniukai & Mergaitès \\
\hline $\begin{array}{l}\text { Paprastai rūko } \\
\text { namuose (rūkantys } \\
\text { mokiniai) }\end{array}$ & 91 & 34 & 51 & 34 \\
\hline $\begin{array}{l}\text { Perka cigaretes } \\
\text { parduotuvèje ar } \\
\text { kioske (rūkantys } \\
\text { mokiniai) }\end{array}$ & 149 & $\mathbf{1 3 , 4}$ & $\mathbf{1 4 , 4 ^ { * }}$ & $\mathbf{1 0 , 5 ^ { * }}$ \\
\hline $\begin{array}{l}\text { Nusipirko } \\
\text { tabako produktą } \\
\text { neatsižvelgus i } \\
\text { amžiù (bandžiusių } \\
\text { pirkti) }\end{array}$ & $\mathbf{4 1 , 2}$ & $\mathbf{3 9 , 5}$ & $\mathbf{2 5 , 6 ^ { * }}$ & $\mathbf{1 4 , 6 ^ { * }}$ \\
\hline
\end{tabular}

3 lentelè. Rūkymas aplinkoje ir požiūris ị kitų rūkymą

Pastaba: Ženklas " reiškia statistiškai patikima $(p<0,05)$ skirtuma tarp pirmo $(2005$ m.) ir kartotinio (2012 m.) tyrimu rezultatu. Ženklo nebuvimas reiškia p $>0,05$

\begin{tabular}{|c|c|c|c|c|}
\hline \multirow{3}{*}{ Klausimai (Teiginiai) } & \multicolumn{4}{|c|}{ Tyrimo metai, atsakymai (abs.sk., proc) } \\
\hline & \multicolumn{2}{|c|}{$2005 \mathrm{~m}}$. & \multicolumn{2}{|c|}{$2012 \mathrm{~m}}$. \\
\hline & Berniukai & Mergaitès & Berniukai & Mergaitès \\
\hline $\begin{array}{l}\text { Gyvena namuose, kur } \\
\text { rūkoma šalia jų bent } \\
\text { vieną dieną iš septynių }\end{array}$ & $\begin{array}{c}608 \\
\mathbf{4 1 , 8}\end{array}$ & $\begin{array}{r}574 \\
\mathbf{3 9 , 7}\end{array}$ & $\begin{array}{c}302 \\
\mathbf{3 3 , 0}\end{array}$ & $\begin{array}{c}322 \\
\mathbf{3 3 , 1 ^ { * }}\end{array}$ \\
\hline $\begin{array}{l}\text { Būna šalia kitų } \\
\text { rūkančių žmonių bent } \\
\text { vieną dieną iš septynių } \\
\text { (ne namuose) }\end{array}$ & $\begin{array}{c}741 \\
\mathbf{5 1 , 0}\end{array}$ & $\begin{array}{c}734 \\
\mathbf{5 0 , 7}\end{array}$ & $\begin{array}{l}473 \\
\mathbf{5 1 , 6}\end{array}$ & $\begin{array}{c}533 \\
\mathbf{5 4 , 5 ^ { * }}\end{array}$ \\
\hline $\begin{array}{l}\text { Mano, kad rūkyti } \\
\text { viešose vietose turètų } \\
\text { būti draudžiama }\end{array}$ & $\begin{array}{l}1009 \\
\mathbf{7 1 , 3}\end{array}$ & $\begin{array}{l}1072 \\
\mathbf{7 4 , 8}\end{array}$ & $\begin{array}{r}676 \\
\mathbf{7 4 , 1}\end{array}$ & $\begin{array}{c}788 \\
\mathbf{8 1 , 2 *}\end{array}$ \\
\hline $\begin{array}{l}\text { Mano, kad kitụ } \\
\text { rūkymas jiems kenkia }\end{array}$ & $\begin{array}{l}1046 \\
72,6\end{array}$ & $\begin{array}{l}1274 \\
\mathbf{8 8 , 3}\end{array}$ & $\begin{array}{c}757 \\
\mathbf{8 2 , 5 *}\end{array}$ & $\begin{array}{l}871 \\
\mathbf{8 9 , 1}\end{array}$ \\
\hline $\begin{array}{l}\text { Rūko bent vienas iš } \\
\text { tèvų }\end{array}$ & $\begin{array}{l}756 \\
\mathbf{5 2 , 1}\end{array}$ & $\begin{array}{l}795 \\
\mathbf{5 4 , 8}\end{array}$ & $\begin{array}{l}466 \\
\mathbf{5 0 , 7}\end{array}$ & $\begin{array}{r}501 \\
\mathbf{5 1 , 2} \\
\end{array}$ \\
\hline $\begin{array}{l}\text { Rūko beveik visi ar } \\
\text { visi draugai }\end{array}$ & $\begin{array}{l}274 \\
19,3\end{array}$ & $\begin{array}{l}250 \\
17,3\end{array}$ & $\begin{array}{l}174 \\
19,0\end{array}$ & $\begin{array}{l}165 \\
\mathbf{1 6 , 9}\end{array}$ \\
\hline
\end{tabular}

m. sumažèjo procentas berniukų, bent kartą pabandžiusių rūkyti cigaretes, nuo 71,3 proc. iki 67,1 proc., tačiau procentas mergaičių, bent kartą pabandžiusių rūkyti cigaretes, išaugo nuo 51,6 proc. 2005 metais iki 56,0 proc. - 2012 metais $(p<0,05)$. Sumažèjo procentas berniukų, rūkiusių kitoki tabako gaminị negu cigaretes per 30 dienų, bei sumažèjo procentas berniukų, galvojančių, jog berniukams rūkymas prideda patrauklumo $(\mathrm{p}<0,05)$. Tačiau padidèjo procentas berniukų ir mergaičių, tvirtai manančių pradèti rūkyti per ateinančius 12 mènesių, galvojančių, jog rūkantys berniukai turi daugiau draugų, bei procentas mergaičių, per 30 dienų rūkiusių kitą nei cigaretès tabako gaminị.

4 lentelè. Metimas rūkyti

Pastaba: Ženklas " reiškia statistiškai patikima $(p<0,05)$ skirtuma tarp pirmo $(2005$ m.) ir kartotinio (2012 m.) tyrimu rezultatu. Ženklo nebuvimas reiškia $p>0,05$

\begin{tabular}{|l|c|c|c|c|}
\hline \multirow{2}{*}{$\begin{array}{l}\text { Klausimai } \\
\text { (Teiginiai) }\end{array}$} & \multicolumn{4}{|c|}{ Tyrimo metai, atsakymai (abs.sk., proc) } \\
\cline { 2 - 5 } & \multicolumn{2}{|c|}{$\mathbf{2 0 0 5} \mathbf{~ m . ~}$} & \multicolumn{2}{c|}{$\mathbf{2 0 1 2} \mathbf{~ m . ~}$} \\
\cline { 2 - 5 } & Berniukai & Mergaitès & Berniukai & Mergaitès \\
\hline Norètų mesti & 132 & 64 & 81 & 45 \\
rūkyti dabar & $\mathbf{6 8 , 0}$ & $\mathbf{6 4 , 6}$ & $\mathbf{6 1 , 3 *}$ & $\mathbf{5 2 , 3 *}$ \\
\hline Bandè mesti per & 158 & 114 & 128 & 113 \\
12 mènesių & $\mathbf{6 2 , 9}$ & $\mathbf{6 5 , 3}$ & $\mathbf{6 5 , 3 *}$ & $\mathbf{6 5 , 3}$ \\
\hline $\begin{array}{l}\text { Yra gavę pagalbą } \\
\text { noredami mesti }\end{array}$ & 335 & 184 & 192 & 171 \\
rūkyti & $\mathbf{7 4 , 6}$ & $\mathbf{6 6 , 4}$ & $\mathbf{5 2 , 0 *}$ & $\mathbf{5 3 , 7 *}$ \\
\hline
\end{tabular}

5 lentelè. Informacinès priemonès ir cigarečių reklama

Pastaba: Ženklas " reiškia statistiškai patikima $(p<0,05)$ skirtuma tarp pirmo $(2005$ m.) ir kartotinio (2012 m.) tyrimu rezultatu. Ženklo nebuvimas reiškia $p>0,05$

\begin{tabular}{|c|c|c|c|c|}
\hline \multirow{3}{*}{$\begin{array}{l}\text { Klausimai } \\
\text { (Teiginiai) }\end{array}$} & \multicolumn{4}{|c|}{ Tyrimo metai, atsakymai (abs. sk., proc) } \\
\hline & \multicolumn{2}{|c|}{$2005 \mathrm{~m}}$. & \multicolumn{2}{|c|}{$2012 \mathrm{~m}}$. \\
\hline & $\begin{array}{c}\text { Berniu- } \\
\text { kai }\end{array}$ & $\begin{array}{l}\text { Mergai- } \\
\text { tès }\end{array}$ & $\begin{array}{c}\text { Berniu- } \\
\text { kai }\end{array}$ & $\begin{array}{c}\text { Mergai- } \\
\text { tès }\end{array}$ \\
\hline $\begin{array}{l}\text { Matè bent keletą } \\
\text { prieš rūkymą } \\
\text { nukreiptų pranešimų } \\
\text { žiniasklaidoje per } \\
\text { praejjusias } 30 \text { dienų }\end{array}$ & $\begin{array}{l}1137 \\
\mathbf{8 1 , 0}\end{array}$ & $\begin{array}{l}1209 \\
\mathbf{8 4 , 4}\end{array}$ & $\begin{array}{r}772 \\
\mathbf{8 4 , 9}\end{array}$ & $\begin{array}{c}843 \\
86,4\end{array}$ \\
\hline $\begin{array}{l}\text { Matè cigarečių } \\
\text { reklamą bent viename } \\
\text { reklaminiame stende } \\
\text { ar pan. per praejjusias } \\
30 \text { dienų }\end{array}$ & $\begin{array}{l}988 \\
\mathbf{6 9 , 6}\end{array}$ & $\begin{array}{l}1021 \\
\mathbf{7 1 , 6}\end{array}$ & $\begin{array}{r}637 \\
70,2\end{array}$ & $\begin{array}{l}708 \\
\mathbf{7 3 , 1}\end{array}$ \\
\hline $\begin{array}{l}\text { Matė bent vieną } \\
\text { cigarečių reklamą } \\
\text { laikraščiuose ar } \\
\text { žurnaluose per } \\
\text { praejjusias } 30 \text { dienų }\end{array}$ & $\begin{array}{l}948 \\
\mathbf{6 6 , 2}\end{array}$ & $\begin{array}{r}817 \\
\mathbf{5 8 , 7}\end{array}$ & $\begin{array}{c}504 \\
\mathbf{5 1 , 9 *}\end{array}$ & $\begin{array}{c}430 \\
\mathbf{4 7 , 4 ^ { * }}\end{array}$ \\
\hline $\begin{array}{l}\text { Turi koki nors daiktą } \\
\text { su cigarečių firmos } \\
\text { logotipu }\end{array}$ & $\begin{array}{l}360 \\
27,0\end{array}$ & $\begin{array}{l}197 \\
\mathbf{1 4 , 1}\end{array}$ & $\begin{array}{c}105 \\
\mathbf{1 1 , 8 *}\end{array}$ & $\begin{array}{c}62 \\
6,5^{*}\end{array}$ \\
\hline $\begin{array}{l}\text { Buvo pasiūlyta } \\
\text { nemokamai cigarečių } \\
\text { tabako kompanijos } \\
\text { atstovo }\end{array}$ & $\begin{array}{l}237 \\
17,4\end{array}$ & $\begin{array}{l}87 \\
\mathbf{6 , 2}\end{array}$ & $\begin{array}{c}85 \\
9,5 *\end{array}$ & $\begin{array}{l}46 \\
\mathbf{4 , 8}\end{array}$ \\
\hline
\end{tabular}


6 lentelè. Rūkymo profilaktinis mokymas mokykloje Pastaba: Ženklas "reiškia statistiškai patikima $(p<0,05)$ skirtuma tarp pirmo $(2005$ m.) ir kartotinio (2012 m.) tyrimu rezultatu. Ženklo nebuvimas reiškia p>0,05

\begin{tabular}{|c|c|c|c|c|}
\hline \multirow{3}{*}{$\begin{array}{l}\text { Klausimai } \\
\text { (Teiginiai) }\end{array}$} & \multicolumn{4}{|c|}{ Tyrimo metai, atsakymai (abs.sk., proc) } \\
\hline & \multicolumn{2}{|c|}{$2005 \mathrm{~m}}$. & \multicolumn{2}{|c|}{$2012 \mathrm{~m}}$. \\
\hline & $\begin{array}{c}\text { Berniu- } \\
\text { kai }\end{array}$ & $\begin{array}{l}\text { Mergai- } \\
\text { tès }\end{array}$ & $\begin{array}{c}\text { Berniu- } \\
\text { kai }\end{array}$ & $\begin{array}{c}\text { Mergai- } \\
\text { tès }\end{array}$ \\
\hline $\begin{array}{l}\text { Praèjusiais metais } \\
\text { pamokų metu } \\
\text { buvo kalbėta apie } \\
\text { rūkymo pavojus }\end{array}$ & $\begin{array}{c}553 \\
\mathbf{3 9 , 2}\end{array}$ & $\begin{array}{c}424 \\
29,6\end{array}$ & $\begin{array}{c}492 \\
\mathbf{5 3 , 9 *}\end{array}$ & $\begin{array}{c}552 \\
\mathbf{5 6 , 8 ^ { * }}\end{array}$ \\
\hline $\begin{array}{l}\text { Praejjusiais } \\
\text { metais diskutavo } \\
\text { pamokose apie jų } \\
\text { amžiaus žmonių } \\
\text { rūkymo priežastis }\end{array}$ & $\begin{array}{l}459 \\
\mathbf{3 2 , 7}\end{array}$ & $\begin{array}{l}403 \\
\mathbf{2 8 , 3}\end{array}$ & $\begin{array}{c}419 \\
\mathbf{4 6 , 6} *\end{array}$ & $\begin{array}{c}496 \\
\mathbf{5 1 , 1 *}\end{array}$ \\
\hline $\begin{array}{l}\text { Praejusiais metais } \\
\text { buvo mokomi } \\
\text { pamoku metu } \\
\text { apie tabako } \\
\text { vartojimo poveiki }\end{array}$ & $\begin{array}{c}523 \\
\mathbf{3 7 , 1}\end{array}$ & $\begin{array}{r}388 \\
27,2\end{array}$ & $\begin{array}{c}438 \\
\mathbf{4 8 , 2}\end{array}$ & $\begin{array}{c}501 \\
\mathbf{5 1 , 8}\end{array}$ \\
\hline
\end{tabular}

Iš antros lentelès matyti, kad 2012 metais sumažejo berniukų ir mergaičių procentas rūkančių namuose, perkančių cigaretes parduotuvejje $(p<0,05)$. Tačiau perkantiems cigaretes parduotuvejje palengvejo ir ịsigijimas, didesniam procentui mokinių, cigaretes perkančių parduotuvejje, jos buvo parduodamos neatsižvelgiant ị amžių.

Iš trečios lentelès matyti, jog sumažejjo procentas vaikų, šalia kurių rūkoma namuose bent vieną dieną iš septynių. Tačiau nepasikeite procentas rūkančių tėvų ir liko aukštas per 50 proc., bei draugų rūkymas - 19 proc. berniukų ir 16,9 proc. mergaičių nurode, jog rūko beveik visi ar visi jų draugai. Didesnis procentas mergaičių nurodè, kad jos būna rūkančių aplinkoje (ne namuose), daugiau jų galvoja, kad rūkymas viešose vietose turètų būti draudžiamas $(81,2$ proc.), daugiau berniukų mano (82,5 proc.), kad kitų rūkymas jiems kenkia.

Iš ketvirtos lentelès matyti, jog 2012 metais ženkliai $(p<0,05)$ sumažèjo procentas rūkančių mokinių, norinčių mesti rūkyti dabar, o norintys mesti rūkyti rečiau gavo pagalbą iš aplinkinių. Padidejo procentas berniukų, bandžiusių mesti rūkyti per 12 mènesių.

Iš penktos lentelès matyti, jog 2012 metais daugelis vaikų - 84,9 proc. berniukų ir 86,4 proc. mergaičių per 30 dienų matè prieš rūkymą nukreiptų pranešimų žiniasklaidoje. Cigarečių reklamą bent viename reklaminiame stende per praejjusias 30 dienų matè 70,2 proc. berniukų ir 73,1 proc. mergaičių. Lyginant 2005 ir 2012 metų tyrimus, statistiškai patikimo skirtumo tarp mokinių procento, pastebejusių re-
7 lentelè. 7-9 klasių mokinių rūkymo ypatybès Lietuvos atrankose (GYTS 2001 - 2009m.) ir Kauno rajono mokyklose - 2012 m. Pastaba: Ženklas " reiškia statistiškai patikima $(p<0,05)$ skirtuma tarp 2009 metu Lietuvos mokiniu GYTS tyrimo ir 2012 metu mokiniu tyrimo rezultatu Kauno rajone.

\begin{tabular}{|c|c|c|c|c|c|}
\hline \multirow{3}{*}{$\begin{array}{l}\text { Klausimai } \\
\text { (Teiginiai) }\end{array}$} & \multirow{3}{*}{ Lytis } & \multicolumn{4}{|c|}{ Tyrimo metai, atsakymai (proc.) } \\
\hline & & \multicolumn{3}{|c|}{$\begin{array}{c}\text { GYTS tyrimas } \\
\text { Lietuvoje }\end{array}$} & \multirow{2}{*}{$\begin{array}{c}\begin{array}{c}\text { Tyrimas } \\
\text { Kauno } \\
\text { rajone }\end{array} \\
2012 \\
\end{array}$} \\
\hline & & 2001 & 2005 & 2009 & \\
\hline \multirow{2}{*}{$\begin{array}{l}\text { Bent kartą rūkè } \\
\text { cigaretes }\end{array}$} & Berniukai & 82,8 & 80,0 & 80,4 & 67,1 \\
\hline & Mergaitès & 68,1 & 65,6 & 67,6 & 56,0 \\
\hline \multirow{2}{*}{$\begin{array}{l}\text { Pastarajjị mènesị } \\
\text { rūkė cigaretes }\end{array}$} & Berniukai & 37,6 & 33,8 & 34,4 & 24,9 \\
\hline & Mergaitès & 29,6 & 25,9 & 27,1 & 16,7 \\
\hline \multirow{2}{*}{$\begin{array}{l}\text { Rūko bent vienas } \\
\text { iš tèvų }\end{array}$} & Berniukai & 61,7 & 56,8 & 58,4 & 50,7 \\
\hline & Mergaitès & 64,1 & 59,2 & 62,1 & 51,2 \\
\hline \multirow{2}{*}{$\begin{array}{l}\text { Būna šalia kitų } \\
\text { rūkančių žmonių } \\
\text { bent vieną dieną } \\
\text { iš septynių (ne } \\
\text { namuose) }\end{array}$} & Berniukai & 69,2 & 63,8 & 66,5 & 51,6 \\
\hline & Mergaitès & 64,2 & 65,1 & 63,3 & 54,5 \\
\hline \multirow{2}{*}{$\begin{array}{l}\text { Nusipirko } \\
\text { tabako produktą } \\
\text { neatsižvelgus i } \\
\text { amžių (rūkančių) }\end{array}$} & Berniukai & 58,2 & 50,7 & 53,5 & 65,5 \\
\hline & Mergaitès & 77,6 & 61,0 & 64,8 & 70,2 \\
\hline \multirow{2}{*}{$\begin{array}{l}\text { Praejusiais } \\
\text { metais diskutavo } \\
\text { pamokose apie jų } \\
\text { amžiaus žmonių } \\
\text { rūkymo priežastis }\end{array}$} & Berniukai & 38,4 & 34,3 & 51,3 & 46,6 \\
\hline & Mergaitès & 35,7 & 35,5 & 56,5 & 51,1 \\
\hline
\end{tabular}

klamą už rūkymą stenduose ir prieš rūkymą žiniasklaidoje, nèra, tačiau ženkliai sumažejo mokinių procentas mačiusių bent vieną cigarečių reklamą laikraščiuose ar žurnaluose per 30 dienų $(p<0,05) .2012$ metais nustatytas mažesnis procentas mokinių, turinčių kokị nors daiktą su cigarečių firmos logotipu, mažesnis procentas berniukų nurodé, jog firmos atstovai jiems nemokamai siūlè cigarečiu $(p<0,05)$.

Iš šeštos lentelès matyti, jog 2012 metais lyginant su 2005 metų tyrimu sustiprèjo profilaktinis darbas Kauno rajono mokyklose: didesnis procentas mokinių, berniukų ir mergaičių nurodè, jog pamokose su jais buvo kalbeta apie rūkymo keliamus pavojus, diskutavo apie jų amžiaus žmonių rūkymo priežastis ar neigiamą tabako vartojimo povei$\mathrm{kic}(\mathrm{p}<0,05)$.

Iš lentelès 7 matyti, kad lyginant su 2009 metų GYTS tyrimu Lietuvoje, Kauno rajono rūkymo ir su juo susijusio elgesio rodikliai yra pastebimai geresni. Tačiau mokinių Kauno rajone, kurie nusipirko tabako produktą (cigaretes), neatsižvelgiant i jų amžių, procentas yra didesnis, o procentas mokinių, kurie pamokose diskutavo apie jų amžiaus žmonių rūkymo priežastis - mažesnis negu GYTS tyrime dalyvavusių mokinių, reprezentuojančių Lietuvą 2009 metais. 


\section{Rezultatų aptarimas}

2012 metais atlikto mūsų tyrimo duomenimis, per 30 dienų rūkè cigaretes 24,9 proc. berniukų ir 16,7 proc. mergaičių. Kitame tyrime [17] 2011 metais Kauno rajone buvo tiriami 5-11 klasių mokiniai taikant HBSC projekto klausimus. Nustatyta, jog 2011 metais rūke 24,7 proc. berniukų ir 17,4 proc. mergaičių. Abiejuose tyrimuose rūkančių mokinių procentas beveik identiškas, tačiau dèl skirtingų apklausos klausimų ir dalyvių amžiaus sunku šiuos duomenis interpretuoti. Vykdant 2012 metų 7-9 klasių mokinių rūkymo tyrimą buvo tiketasi, jog sumažejęs rūkymo profilaktikos priemonių taikymas po 2005 metų Kauno rajone sulètins rūkymo paplitimo ir su juo susijusio elgesio dinamiką. Tačiau tyrimas parode, jog 2012 metais, lyginant su 2005 metų tyrimu, daugelis su rūkymu susijusio mokinių požiūrio bei elgesio rodiklių toliau keitèsi sveikatai palankia kryptimi. İdomu pažymèti, kad Lietuvos GYTS projekte iki 2009 m. pagal šiame straipsnyje analizuojamus rodiklius (7 lentelè) žymesnių mokinių rūkymo paplitimo pokyčiu nebuvo. Lyginant su 2009 m. Lietuvos GYTS tyrimu, Kauno rajone 7-9 klasių mokinių rodikliai ženkliai geresni. Tačiau profilaktinius pokalbius apie rūkymą pamokų metu Kauno rajone mini mažesnis procentas mokinių, o galimybę nusipirkti cigarečių nurodè didesnis procentas. Kai kuriuos mokinių požiūrio ir elgesio pakitimus galima susieti su rūkymą ribojančia sveikatos politika Lietuvoje, pavyzdžiui, 2012 metais procentas 7-9 klasių mokinių, Kauno rajone mačiusių cigarečių reklamą laikraščiuose ar žurnaluose, buvo ženkliai mažesnis $(\mathrm{p}<0,05)$, sumažejo cigarečių firmų aktyvumas - mažesnis procentas mokinių turi kokị nors daiktą su firmų logotipu, mažesnis procentas nurodè, kad firmos atstovas siūlè jiems cigarečių nemokamai, mažiau mokinių rūko namuose, mažesnis jų procentas perka cigaretes parduotuveje. Kita vertus, didesnis procentas mokinių lengviau nusiperka cigaretes - jiems cigaretès buvo parduotos neatsižvelgiant $i$ amžių. Toliau lieka rūkymą skatinanti aplinka namie - 50 proc. mokinių bent vienas iš tėvų yra rūkantis, 10-14 proc. 7-9 klasių mokinių gali rūkyti namuose. Kartu šio tyrimo duomenys dar kartą patvirtino, jog planuojant rūkymo prevencijos priemones mokykloje ir vertinant jų efektyvumą bei rūkymo kitimus reikia atsižvelgti ne tik ị rūkymo paplitimą, bet ir ị mokinių su rūkymu susijusio elgesio, požiūrio ir rūkyti skatinančios aplinkos veiksnius. Nežiūrint $i$ t teigiamus pokyčius tyrimo rezultatai patvirtina ilgalaikès rūkymo profilaktikos programos reikalingumą Kauno rajone.

\section{Išvados}

1. 2012 metais, lyginant su 2005 metais, Kauno rajono mokyklose bandžiusių rūkyti 7-9 klasių berniukų procen- tas sumažèjo, o mergaičių išaugo (p 0,05), tačiau išlieka aukštas $-67,1$ proc. berniuku ir 56 proc. mergaičių; per pastarąsias 30 dienų rūkè cigaretes 24,9 proc. berniukų ir 16,7 proc. mergaičių, rūkẻ kitokị negu cigaretes tabako gamini 13,2 proc. berniukų ir 11,9 proc. mergaičių; 7,3 proc. berniukų ir 5,1 proc. mergaičių tvirtai manè pradèti rūkyti per artimiausius 12 mènesių.

2. Sumažèjo procentas mokinių, rūkančių namuose, iki 14,4 proc. berniuku ir 10,5 proc. mergaičiu ir perkančių cigaretes parduotuveje $(p<0,05)$, tačiau palengvejjo cigarečių isigijimas parduotuveje - perkantiems cigaretes didesniam procentui mokinių jas pardavè neatsižvelgiant ị amžių.

3. 82,5 proc. berniuku ir 89,1 proc. mergaičiu mano, kad kitu rūkymas jiems kenkia, 74,1 ir 81,2 proc. proc. mano, kad viešose vietose rūkyti turètų būti draudžiama, tačiau 2012 metais sumažejo procentas mokinių, norinčių mesti rūkyti, o norintys mesti iš kitu žmonių gavo mažiau palaikymo rūkymo metimui $(\mathrm{p}<0,05)$.

4. 2012 metais išlieka aukštas procentas mokinių, kuriems visuomenèje (ne namie) tenka būti šalia rūkančių žmoniu (52-55 proc.), rūko beveik visi arba visi draugai (17-19 proc.), bent vienas iš respondentų tèvų yra rūkantis (51 proc.), tačiau mažesnis respondentų procentas (33 proc.) nurodè, kad namuose šalia jų rūkoma.

5. 2012 metais sumažèjo procentas mokinių, turinčių kokị nors daiktą su cigarečių firmos logotipu, sumažejo atvejų, kai mokiniams firmos atstovai siūlè paimti cigarečių nemokamai.

6. 2012 metais didesnis procentas mokinių nurodè, jog pamoku metu buvo kalbama apie rūkymo žalą, diskutavo apie rūkymo pavojus $(\mathrm{p}<0,05)$. Tačiau tokių mokinių procentas 2012 metais buvo mažesnis lyginant su GYTS tyrimu Lietuvoje 2009 metais.

\section{Literatūra}

1. Smoking and its effects on health. Report of a WHO Expert Committee. Technical Report Series 568, WHO, Geneva, 1975; 8.

2. Peto R, Lopez AD, Boreham J, Thun M, Heath CJr. Mortality from Smoking in Developed Countries 1950-2000. Indirect estimates from national vital statistics. Oxford medical publications. Oxford University Press, 1994.

3. WHO framework Convention on Tobacco Control. Geneva, World Health Organisation, 2003.

4. The European Health Report 2012 Charting the way to WellBeing. WHO Regional office for Europe. Copenhagen, 2013; 40-41.

5. Glasunov IS, Dowd IE, Baubinienė A, Grabauskas V, Sturmans F, Schuurman IH. (Eds.) The Kaunas- Rotterdam Intervention Study. Elsevier (North-Holland Biomedical Press) Amsterdam. - New York: Oxford, 1981.

6. Bluzhas J, Stalioraitytė E, Prochorskas R, Babarskienė R, 
Domarkienè S, Gostautas A. The World Health Organization MONICA Project (Monitoring Trends and Determinants in Cardiovascular Disease): A Major International Collaboration. J. Clin. Epidemiol. 1988; 2(41).

7. Hibell B, Anderson B, Bjarnasson T, Ahlstrom S, Balglakireva O. et al. (Eds). The ESPAD Report 2003. Alcohol and other drug use among students in 35 European countries. Stockholm, 2004.

8. Social cohesion for mental well - being among adolescents WHO/HBSC Forum 2007. Copenhagen, WHO Regional Office for Europe, 2008; 268.

9. Global Youth Tobacco Survey. Collaborating Group (Warren Ch.) Differences in Worldwide Tobacco Use by gender. Findings from the Global Youth Tobacco Survey. Journal of School Health, 2003; 73(6):207-2015.

10. Tobacco use among youth: a cross country comparison. The Global Youth Tobacco Survey Collaborative Group. Tobacco control, 2002; 252-270.

11. Goštautas A. National smoking prevention program in Lithuanian schools. Annals of the Kaunas institute of Cardiology, 1994; 1(1): 23-36.

12. Goštautas A., Žardeckaitè - Matulaitienė K. Moksleivių rūkymo profilaktikos galimybès. Mokslo darbai. Socialinis darbas, 2003; 2(4):67-74.

13. Žardeckaitė - Matulaitienė K. Rūkymo profilaktikos programos, pagrịstos socialinès įtakos teoriniu modeliu, taikymo VI ir VII klasių mokiniams efektyvumas. Daktaro disertacija. Kaunas, 2008.

14. Goštautas A., Pilkauskienė I., Žekas R., Žardeckaitė-Matulaitienė K. Mokinių rūkymo profilaktikos efektyvumas Kauno rajone 2002 - 2005 metais. Visuomenès sveikata, 2006; 3(34): 19-25.

15. Goštautas A. Global Youth Tobacco Survey in Lithuania. Visuomenès sveikata. 2003; 3 (22): 24-28.

16. Goštautas A. Mokinių rūkymas Lietuvoje 30 metų laikotarpiu. Lietuvos sveikatos programa: rezultatai ir išvados. Nacionalinès sveikatos tarybos metinis pranešimas. Nacionalinė sveikatos taryba. Vilnius, 2011; 68-70.

17. Zaborskis A. Kauno rajono mokyklų mokinių gyvensena ir savijauta 2011. Kaunas, 2011; 30.

\section{CHANGES IN STUDENTS SMOKING AND RELATED BEHAVIOUR IN KAUNAS REGION FROM 2005 UNTIL 2012}

A. Goštautas, R. Žekas, L. Dilys, N. Goštautaitė Midttun

Key words: students smoking, smoking changes, Global Youth Tobacco Survey (GYTS), Kaunas region, attitude towards smoking, smoking prevention.
Summary

The effectiveness of the globally applicable, continuous, intensive teaching measures were confirmed in Kaunas region schools during the period 2002-2005. The aim of this article is to determine further changes in student smoking, attitudes and behaviour related to smoking in the period of 2005-2012 in the context of the methodology of the Global Youth Tobacco Survey (GYTS). 3250 and 1800 seventh to ninth grade students participated respectively in the surveys of 2005 and 2012 . The questions were divided into 6 thematic groups and in the 2012 survey compared to 2005 there was a significant decrease in the percentage of boys who had tried smoking $(\mathrm{p}<0.05)$ and those who smoked other tobacco product than cigarettes during a past month, but there was an increase in the percentage of students who think to start smoking in the next 12 months and believe that boys who smoke have more friends $(\mathrm{p}<0.05)$. There was a decrease in the percentage of students living in the house where people smoke, who smoke at their home themselves, who buy cigarettes in a store $(\mathrm{p}<0.05)$. However in 2012 a higher percentage of students buying cigarettes in a store indicated that they were sold cigarettes, regardless of their age. In 2012 a lower percentage of students who want to quit smoking received assistance or support for quitting smoking. There was a decrease in the percentage of students who saw at least one cigarette ad in the newspapers or magazines within 30 days and in the percentage of those who were offered free cigarettes or have an object with a cigarette brand logo. In 2012 a higher percentage of students indicated that they discussed about the dangers of smoking at school during the lessons but lower percentage than in GYTS survey in Lithuania in 2009. The changes in smoking prevalence, attitudes and behavioural more favourable towards health were found in 2005-2012 among 7-9th grade students in Kaunas region schools, but level of smoking is still dangerous to their health.

Correspondence to: antanas.gostautas@gmail.com

Gauta 2013-10-06 